\title{
More is Better: The Influence of Collective Female Descriptive Representation on External Efficacy
}

\author{
Lonna Rae Atkeson and Nancy Carrillo
}

University of New Mexico

This study tests the hypothesis that collective descriptive representation has important benefits for strengthening and legitimizing democratic society. Specifically, we test whether increased proportions of collective female descriptive representation in the statehouse and the presence of a female state executive are important to female citizens' attitudes toward government responsiveness, or external efficacy. We hypothesize that an increase in female collective descriptive representation in the legislative and state executive branches of government will increase female citizens' external efficacy but will be unimportant to males. We pooled American National Election Studies (ANES) data from 1988 to 1998 and used ordered probit techniques to test the hypothesis. In addition to our main independent variable of interest, our model includes state political culture, dyadic descriptive representation, dyadic substantive representation, sociodemographics, political participation, strength of partisanship, and electoral dummy variables as controls. Our results confirm that higher levels of collective female descriptive representation promote higher values of external efficacy for female citizens, suggesting that collective female descriptive representation has important benefits to a democratic society.

$H$ xternal political efficacy is the individual perception that governmen4 tal authorities and institutions are responsive to citizen influence (Balch 1974; Converse 1972). External efficacy is an important and

An earlier version of this article was presented at the American Political Science Association's Annual Meeting in San Francisco, California, August 30-September 2, 2001, and the International Society of Political Psychology, Seattle, Washington, July 1-4, 2000. We would like to thank the following people for their comments and support: Anthony Coveny, Randall Partin, and Cherie Maestas.

Published by Cambridge University Press 1743-923X/07 \$15.00 for The Women and Politics Research

Section of the American Political Science Association.

(C) The Women and Politics Research Section of the American Political Science Association.

DOI: $10.1017 / \mathrm{S} 1743923 \mathrm{X} 0707002 \mathrm{X}$ 
extensively studied political attitude because of its relationship to political participation and its inherent value to a democratic system of government (Abramson 1983). While most studies have focused on explaining external political efficacy with individual factors, our study focuses on the importance of the citizen's larger state political environment and its influence on feelings toward government responsiveness. Specifically, we argue that collective descriptive representation may play an important role in understanding citizen attitudes toward government. This is consistent with a theoretical claim that descriptive representation is important for strengthening the legitimacy of democratic institutions (Mansbridge 1999; Phillips 1998). While legitimacy can take on many different forms, we argue that perceived government responsiveness by elected leaders is one key form. Furthermore, feelings of external efficacy offer a very specific and testable measure of government legitimacy that may provide empirical support to arguments about the value of descriptive representation in elected bodies of government.

Our theoretical focus is on collective descriptive representation, rather than dyadic representation, because we are interested in how the perceived characteristics of the institutions of government may enhance their legitimacy. Collective representation focuses on how well the institution as a whole represents its citizens, while dyadic representation asks how well a specific member of a governing body represents his or her constituents (Weissberg 1978). The attitude of external efficacy is explicitly interested in "government responsiveness" by elected leaders, not dyadic responsiveness, and therefore represents a very direct test of the potential power of collective descriptive representation to help shape political attitudes and opinions. Furthermore, many scholars have argued that descriptive representation contributes to better substantive representation (Dovi 2002; Keiser et al. 2002; Mansbridge 1999; Phillips 1998; Saltzstein 1979; Sapiro 1981; Thompson 1976). The physical characteristics of political institutions, therefore, may affect individual levels of external efficacy. When female, black, Latino, or Asian citizens view their government leaders and largely see white male elected officials, their confidence in government may fall. Likewise, when greater gender and/or ethnic diversity are present, feelings of external efficacy may rise.

We test our hypothesis by leveraging the substantial gender diversity of the American state legislative and executive branches over time. If theoretical claims are accurate, then we expect states with greater gender diversity, or greater collective descriptive representation, to influence female citizens' external efficacy. However, we expect male citizens' 
external efficacy to be unaffected since men are represented by majorities of male legislators at both the state and national level, and therefore their collective descriptive representation is already high.

\section{EXTERNAL EFFICACY AND DESCRIPTIVE REPRESENTATION}

Higher feelings of political efficacy are important because they promote regime stability by keeping citizens committed to the existing democratic governing structure, while lower feelings of external efficacy may lead to democratic instability and economic insecurity (Abramson and Aldrich 1982; Citrin and Green 1986; Erber and Lau 1990; Ginsberg 1982; Pollock 1983). Thus, external political efficacy is one measure of acceptance (or rejection) of democratic political institutions and the legitimacy of government. In addition, research has shown that those with stronger feelings of political efficacy are more likely to be active in all forms of political activity (Campbell et al. 1960; Rosenstone and Hansen 1993).

Most studies have focused on individual-level factors for understanding external efficacy (Clarke and Acock 1989; Finkel 1985, 1987; Ginsberg and Weissberg 1978; Hayes and Bean 1993; Hougland and Christenson 1983; Soss 1999; Stenner-Day and Fischle 1992). We acknowledge their explanatory power, but also consider how contextual or system-level factors, beyond the scope of the individual, may contribute to citizen belief in government responsiveness. Like Marianne Stewart and colleagues (1992), Michele Claibourn and Virginia Sapiro (2001), Jennifer Lawless (2004), and Leslie Schwindt-Bayer and William Mishler (2005), we explore the influence of institutional context on the degree of external efficacy. Theory provides several suspected mechanisms for a relationship between collective descriptive representation and external efficacy.

First, theorists have argued that increases in descriptive representation directly strengthen the legitimacy of the legislative body because it appears more open and accessible (Mansbridge 1999; Phillips 1998). A representative body that shares physical characteristics with its constituency symbolically appears more open to input from more citizens and appears better able to understand citizen interests. Female citizens, therefore, may perceive that their own opinions will have greater value when larger proportions of female representatives are present.

Also, a descriptively representative legislative body encompasses wider points of view, leading to broader legislative deliberation than when the 
diversity among legislators is low (Mansbridge 1999). Women enhance this diversity because of the different backgrounds and priorities they bring to legislative life. For example, women are more likely to have had careers in education, nonprofit interest groups, or volunteerism, while men are more likely to come from business backgrounds (Carroll 1984; Mandel and Dodson 1992; Thomas 1991). Women also historically spend more time involved in family-related issues and on household tasks than men do and have different issue priorities at the mass and elite levels (Alvarez and McCaffery 2000; Bratton and Haynie 1999; Mandel and Dodson 1992; Reingold 2000; Saint-Germain 1989; Shapiro and Mahajan 1986; Thomas 1994; Thomas and Welch 1991). Paralleling the gender gap seen in public opinion polls, studies of legislative roll call votes indicate that women legislators are more likely than men to take liberal positions across a number of social issues (Barrett 1995; Carey, Niemi, and Powell 1998; Diamond 1977; Dodson and Carroll 1991). Not surprisingly then, some research shows that a higher proportion of female representation within a legislature increases the amount of legislative attention to female policy priorities ( Berkman and O'Connor 1993; Burrell 1997; Day 1994; Murphy 1997; Thomas 1991), though not necessarily to policy outputs (Crowley 2004; Tolbert and Steuernagel 2001; Weldon 2002; cf. Schwindt-Bayer and Mishler 2005). This suggests a second potential mechanism for a positive relationship between collective descriptive representation and external efficacy that focuses on women's perceived and/or actual substantive representation concerns.

Relatedly, female politicians may enhance external efficacy because their presence in office suggests to female citizens that government is getting things done, especially on policies that female citizens care about. This theoretical link is supported by research that suggests that women state legislators are policy leaders on “women's issues” (Leader 1977). Female legislators express more concern (Diamond 1977; Reingold 2000), are more likely to serve on related committees, and are more likely to write, propose, and mobilize support for them (Diamond 1977; Reingold 2000; Thomas 1994). Female politicians are also seen as more competent on compassion issues (e.g., heath care, education), issues that are often more important to female citizens (Leeper 1991; Mueller 1986; Rosenwasser and Seale 1988; Sapiro 1981/82, 1983).

In summary, theory suggests that collective representation works to boost female citizens' perceptions of government responsiveness by creating a political atmosphere more inviting to female citizens' input and more cognizant and responsive to female concerns. Empirically, re- 
search on the influence of female leaders on female citizens supports the argument that female representation matters. Female citizens are more likely to remember an elected official or candidate's name when he or she is a woman (Burns, Schlozman, and Verba 2001; Koch 1997; Verba, Burns, and Schlozman 1997), suggesting that women pay more attention to politics when women are present. More broadly, research has repeatedly shown that the presence of competitive female candidates positively influences female political engagement, including an increase in political interest, political knowledge, the likelihood of influencing another's vote choice, internal efficacy, political discussion, political activity, attention to news, open-ended comments on parities, and a decrease in the percentage of "don't know" responses (Atkeson 2003; Burns, Schlozman, and Verba 2001; Hansen 1997; Koch 1997; Sapiro and Conover 1997).

The gender and politics literature has also examined the role that dyadic descriptive representation plays on external efficacy, with mixed results, perhaps due to measurement and selection issues. Nancy Burns, Kay Lehman Schlozman, and Sidney Verba $(2001,344)$ find evidence that women's political efficacy is enhanced by the presence of a statewide female incumbent or candidate, suggesting a role for dyadic descriptive representation. ${ }^{1}$ Lawless $(2004,90)$ provides further support, but in inexplicable ways. Her results show that female U.S. House representation increases the external efficacy of men, but not women, while having a female Senator influences men and women. In terms of collective representation, neither Lawless $(2004,90)$, in an American examination of external efficacy, ${ }^{2}$ nor Claibourn and Sapiro $(2001,27)$, in a 14-nation comparative examination of attitudes toward government satisfaction, find an effect. Schwindt-Bayer and Mishler (2005), however, find in a comparative study of 31 nations that female citizens have greater confidence in parliament when women represent larger proportions of the lower house.

The broader minority politics literature also suggests that descriptive representation is important to political empowerment, participation, and attitudes toward government. For example, Katherine Tate (2001) finds that African-American citizens feel more favorable to their member of

1. However, the political efficacy scale of Burns, Schlozman, and Verba $(2001,105)$ is an index of local and national internal and external efficacy that does not provide consistent results when separated. Also, unpublished results from Atkeson (2003) indicate no intergender contest effect for external efficacy, and Tate (2003) shows no dyadic effect of representation on efficacy for blacks.

2. However, this analysis is restricted to those citizens who can place their member of Congress on the ANES thermometer scores, creating generalization problems to the larger public. 
Congress when he or she is African American than when he or she is white, though it is important to note that she found no dyadic effect of representation on political efficacy (p. 140). She does, however, report an interesting positive relationship between perceived descriptive representation and both approval of Congress and trust in government (2003, 148). Similarly, Stacy Burnett Gordon and Gary Segura (2002) find evidence that collective Latino descriptive representation has a positive influence on legislative job performance.

While most citizens probably know the gender of their state executive, is it likely that they are aware of the presence or absence of women in their state legislatures? We argue that citizens are probably more or less aware of the gender composition of their state legislatures. ${ }^{3}$ Certainly few citizens know the exact proportion of women in their statehouses, but more women in office increases the general activity level by elite women, and therefore more women are visible political players. We also know that positions of power for women legislators are correlated with their relative overall numbers in the legislative body. According to Marcia Lynn Whicker and Malcolm Jewell (1998, 165), "The proportion of leaders who are female is roughly the same as the proportion of female legislators." Furthermore, when more women are in these offices and play a larger role in the leadership of these legislative bodies, they are more likely to receive substantial press coverage. Visibility from leadership positions and press coverage promotes an environment wherein women citizens can see women politicians in action.

There may also be an effect from collective female descriptive representation at the state executive level. Governors receive a great deal of media attention and, behind the president, are the most recognized elected officials (Hinckley, Hofstetter, and Kessel 1974; Squire and Fastnow 1994). If a woman holds the governorship, the greater visibility of the office may enhance women citizens' perceptions of government responsiveness. However, the degree of power associated with the governorship varies greatly by state, and regardless, governors must work with their state legislature. If small numbers of women exist in the legislative branch, a single prominent female executive may do little to enhance feelings of government responsiveness. ${ }^{4}$ Nevertheless, given the nature and prominence of the office, we believe that it is theoretically impor-

3. Though we do not know if this is true for women, Tate (2003) shows that blacks, on average, have a fairly accurate picture of their collective descriptive representation in Congress.

4. The correlation between the proportion of women in the state legislature and the presence of a woman governor is negative, but it is positive with the presence of a female member of Congress. 
tant enough to include as a measure of collective female descriptive representation.

Thus, it seems a theoretical and empirical possibility that collective description representation may matter in American politics. Yet, compared to men, women historically have held fewer seats in government, although they have been making substantial gains over the past several decades. ${ }^{5}$ At the national legislative level, they have risen threefold, from about $5 \%$ in 1988 to $15 \%$ in 2006. Likewise, women governors have been elected in several states. And at the state legislative level, there is a wide range in the proportions of women legislators, from one-third female for most of the past decade in some states (e.g., Arizona and Washington) to less than one in 10 female legislators in other states (e.g., Alabama and Kentucky). Such differences in collective descriptive representation across states and years allow us to test whether collective descriptive representation influences how women citizens feel about the responsiveness of government. We hypothesize that larger proportions of women elected leaders will increase women's confidence in government, or external efficacy. Men, on the other hand, will be unaffected since increasing numbers of women in these offices have not displaced majority proportions of men.

\section{ALTERNATIVE THEORIES OF EXTERNAL EFFICACY: DYADIC REPRESENTATION, SUBSTANTIVE REPRESENTATION, AND STATE POLITICAL CULTURE}

Alternatively, female citizen's external efficacy may have little to do with a greater presence of female politicians. There exist three other plausible explanations for differences in women's external efficacy on an individual and state-by-state basis. We have argued that external efficacy represents a value that emphasizes collective over dyadic representation. However, the presence of a dyadic representative of the same ethnic background has been shown to reduce alienation (Pantoja and Segura 2002) and may increase feelings of government responsiveness among women citizens. Though it is compelling at its face, we argue that this effect is unlikely for two reasons. First, the dependent variable of interest analyzed here, external efficacy, is explicitly interested in government responsiveness, not the feelings toward a single leader. Second, even if a

5. Information on women in state legislatures, women in the U.S. Congress, and women state executives come from the Center for American Women and Politics at Rutgers University. 
constituent is represented by a "like" political leader, it is reasonable for the female citizen to believe that in the aggregate, her interests are marginalized without some threshold of collective descriptive representation (Hero and Tolbert 1995). Nevertheless, for a robust test of our model we will include national dyadic representation as an important control. ${ }^{6}$

A second explanation is that substantive party representation increases the likelihood of government responsiveness (Lawless 2004). Party offers substantive representation cues, since parties, especially within states, offer a more cohesive ideology and policy agenda. While party offers a potentially better cue than gender, we argue that it is unlikely to influence external efficacy because the party of a representative is not easily perceived and can be somewhat costly to obtain relative to descriptive factors, especially gender. Nevertheless, it is an important control and could be either dyadic or collective, and so we consider both.

A third alternative explanation of women's external efficacy recognizes the unique beliefs and historical roots of the citizens that settled the individual states, and it is best characterized by the state political culture work of Danile Elazar (1984). His theory recognizes three distinct political subgroups, each reflecting a different orientation to politics. The moralistic political culture expects an active citizenry, a professional bureaucracy, and an active government all working for the benefit of the state, suggesting that states having this culture possess the most likely environment for an electorate with greater feelings of external efficacy. The individualistic political culture expects citizens to pursue their self-interest with bureaucratic assistance and a weak government, making it somewhat likely to encourage feelings of government responsiveness. A traditionalistic government emphasizes the role of elites in political activity, possesses a weak bureaucracy, and possesses a state government whose purpose is to maintain the status quo, resulting in a state political culture that should be least responsive to its citizens (Sharkansky 1969). In addition, scholars have shown that women are more likely to seek elected office in moralistic state political cultures (Hill 1981; Nechemias 1985, 1987) and that state political culture predicts greater proportions of women in the statehouse (Diamond 1977; Norrander and Wilcox 1998). Thus, state political culture might be the real factor in understanding both external efficacy and the proportion of women in

6. We are unable to control for dyadic representation at the state level due to data limitations. However, we argue that our national controls offer satisfactory measures of dyadic representation because if it matters, then it should be visible at the U.S. Congressional level. 
the statehouse, and hence is another important control for a robust test of our model.

\section{DATA AND METHOD}

The data used to test this hypothesis are from the American National Election Studies (ANES) and are pooled from 1988 to 1998. We chose 1988 as our first year because that is the first year NES used a 5-point scale for external efficacy. ${ }^{7}$ These data provide equal numbers of presidential and nonpresidential years and the same survey mode, in-person, for all respondents. ${ }^{8}$ Pooling the data over time provides a data set with more leverage and power, allowing us to overcome the problem of idiosyncratic influences, particularly as our main independent variables of interest are aggregated to the state level for each year. Pooling the crosssectional data therefore gives us large enough state samples to see differences in efficacy levels between men and women across different state contexts and times.

\section{Dependent Variable}

We use the answer to the question "Public officials don't care much what people like me think," also known as "nocare," as our measure of external efficacy. ${ }^{9}$ It is the most often used measure of external efficacy (Morrell 2003). Because our interest is in tapping the legitimacy of government through government responsiveness, this represents the strongest measure for our theoretical question. "Nocare" is measured on a Likert-type scale, ranging from 1 (agree strongly) to 5 (disagree strongly). Thus, higher values indicate stronger feelings of external efficacy. Its mean value is 2.56 and the median is 2 , indicating that more people are not externally efficacious.

7. Because of the change in scale, the response patterns prior to 1988 look very different and, therefore, going back further in time creates measurement problems with the dependent variable.

8. Going back or forward in time creates problems because of changes in question wording, question availability, and survey design.

9. We could also have used "nosay" ("People like me don't have any say about what the government does"), but the empirical and theoretical differences in these variables favor the use of "nocare" as a single measure. Empirically, the variables show significant differences with gender, the key independent variable, suggesting construct validity problems. Moreover, the Cronbach's alpha is less than the traditional cutoff of .70. Theoretically, incumbent-based external efficacy is better represented by "nocare," while procedural fairness and diffuse support is better represented by "nosay" (Craig, Niemi, and Silver 1990; Shingles 1981). 


\section{Independent Variables}

We measure collective descriptive representation in two ways. ${ }^{10}$ The variable "percentage of females in the state legislature" (both upper and lower) represents the most robust measure of collective descriptive representation across states. It is normally distributed, ranging from $4 \%$ to $40 \%$ with a mean of $18 \%$. The significant amount of variance at the state level allows us to test our hypothesis in a robust manner. ${ }^{11}$ The second variable represents the presence (coded 1) or the absence (coded 0) of a female governor. We look at separate models for men and women and an interaction model to determine whether women get a boost, compared to men, from a larger and more gender-diverse system of representation.

Because of their importance as alternative theories for explaining external efficacy, we control for national dyadic descriptive and substantive representation, state substantive collective representation, and state political culture. For dyadic descriptive representation, we created two dummy variables, each coded 1 when a respondent lives in a state or district that is represented in the U.S. Congress by a female legislator. In the interactive model, dyadic representation measures are interacted with the gender (female) of the respondent. For dyadic substantive representation, we created two dummy variables, each coded 1 when a respondent lives in a state or district that is represented by a Senate or House member of the same party. For collective substantive representation, we created a continuous measure that captures the percentage of the state legislature that is in the same party as the respondent. ${ }^{12}$ For state political culture, we use the continuous measure developed by Sharkansky (1969). ${ }^{13}$

We also include a number of individual-level control variables that are known predictors of external efficacy, including the sociodemographic variables education, family income, church attendance, gender, race, and age, as well as internal efficacy, voter turnout behavior, and strength of partisanship. Increases in education levels increase external efficacy (Finkel 1985; Hayes and Bean 1993; Hougland and Christenson 1983;

10. Theoretically, the proportion of women in the U.S. Congress represents an additional measure of collective descriptive representation that we do not include because the small year $\mathrm{N}(6)$ and its small linear distribution over time make it highly sensitive to specification.

11. See Appendix A located at http://www.unm.edu/ atkeson/publications for details.

12. Due to model sensitivity, we did not include a national party representation variable.

13. We also tried a dummy variable approach, but our models were unchanged. 
Soss 1999; Stenner-Day and Fischle 1992). Education is measured on an ordinal scale ranging from 1 (8 grades or less) to 7 (advanced degree). Family income, measured on a scale ranging from 1 (less than $\$ 5,000$ ) to 9 (over $\$ 75,000$ ), has been found to positively influence external efficacy (Hayes and Bean 1993; Soss 1999). Church attendance, measured on an ordinal scale ranging from 0 (does not attend) to 4 (attends almost every week), has been found to be a positive factor (Hayes and Bean 1993; Hougland and Christenson 1983). We have also included the standard variables of race and age, although race is usually not found to be important to external efficacy and age may be positive, negative, or curvilinear (Hayes and Bean 1993; Soss 1999). Race is a dummy variable where black respondents receive a 1 and everyone else a 0 . Age is the actual age of the respondent and age-squared captures any curvilinear relationship.

Following Karen Stenner-Day and Mark Fischle (1992), we have also included internal efficacy. We control for internal efficacy because theoretically, citizens who feel more comfortable with their ability to navigate the political system are likely to feel that government is more responsive - an important psychological resource. Our measure of internal efficacy is the level of agreement with the statement "Politics is too complicated for a person like me to understand." ${ }^{14}$ The variable ranges from 1 to 5 and has a mean value of 2.4 in our sample. ${ }^{15} \mathrm{We}$ also include voting because it has repeatedly been shown that voters are more likely to view their leaders as responsive (Finkel 1985, 1987; Stenner-Day and Fischle 1992). Given that we are interested in making an inference to citizens and not simply to voters, this is an important control. Voting is measured as a dummy variable and is expected to have a positive influence on external efficacy. We also control for strength of partisanship; higher values indicate stronger partisan ties and a greater connection to the political system, which we expect to be positively related to responsiveness. Finally, election-year dummies are included to control for election-year contexts.

We test our model using an ordered probit model because of the ordinal nature and non-normal distribution of the dependent variable, ${ }^{16}$ making ordinary least squares regression inappropriate. Because we are also concerned about the possibility that there may not be within-state inde-

14. This is the only measure of internal efficacy available to us with these data.

15. The internal efficacy of women in our sample is 2.3 and 2.7 for men $(p<.001)$.

16. It is: Strongly Agree 19\%, Agree 39\%, Neither 12\%, Disagree 23\%, Strongly Disagree 6\%. 
pendence, we cluster the data by state, using the Cluster command in Stata 9.2. ${ }^{17}$

\section{RESULTS}

The first column of data in Table 1 presents the full interactive model, the second presents the female model, and the third presents the male model. $^{18}$

Of highest importance to our purposes are the collective descriptive representation variables and their interaction with gender. In the interaction model, the main effects show that the presence of a woman governor influences external efficacy but has no interaction with gender. This is corroborated by the single-gender models that show a positive and significant coefficient. ${ }^{19}$ The effect of a woman governor, therefore, appears to influence both men and women. Perhaps the presence of a woman governor enhances the feeling that all points of view will be represented in government.

The fact that the effect of a female governor is at least as strong for men as it is for women is intriguing and counterintuitive. If further research corroborates this result, we suggest one interpretation. It may be that female executives provide different cues than female legislators because of the different level of office. Governors are executives, sole proprietors of their office, which provides them with greater visibility and media coverage than legislators (Tidmarch, Hyman, and Sorkin 1984). Citizens are also more likely to know their governor's name than their legislators' names (Delli Carpini and Keeter 1996). Such visibility may enhance feelings of external efficacy for both male and female citizens because of perceived characteristics and traits of female leaders, including honesty (Huddy and Terkildsen 1993; Rosenthal 1998), and because female elected officials possess governing styles that emphasize inclusiveness and egalitarianism (Rosenthal 1998).

Other main effects, including gender and the percentage of women in state legislatures, are not significant. However, the interaction of percentage of women in state legislatures with gender is positive and significant, indicating that greater proportions of women in the statehouse

17. The cluster subcommand in stata is a basic hierarchical linear model procedure that adjusts the standard errors. Removing the clustering subcommand leaves the models largely unchanged.

18. The coefficients and standard errors for the election-year dummies are available upon request.

19. Female governor is significant for females in reduced models with demographic and electionyear controls $(\mathrm{b}=.176, \mathrm{p}<.01)$ and with psychological resources $(\mathrm{b}=.146, \mathrm{p}<.001)$. 
Table 1. Ordered probit model of external efficacy, 1988 through 1998

\begin{tabular}{|c|c|c|c|}
\hline & Full Model & Female Model & Male Model \\
\hline \multicolumn{4}{|l|}{ Collective descriptive representation } \\
\hline Proportion of women in state legislatures & -.000 & $.007^{*}$ & -.001 \\
\hline Woman governor & 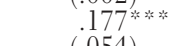 & $.130 \#$ & $.187^{*}$ \\
\hline $\begin{array}{l}\text { Proportion of women in state Legislatures } \\
\text { gender (female) }\end{array}$ & $\begin{array}{l}.034) \\
.007 * \\
(.003)\end{array}$ & & \\
\hline Woman governor"gender (female) & $\begin{aligned}-.036 \\
(.086)\end{aligned}$ & & \\
\hline \multicolumn{4}{|l|}{ Dyadic descriptive representation } \\
\hline Female U.S. senator & .043 & -.066 & .051 \\
\hline Female member of Congress & .063 & -.027 & .071 \\
\hline Female U.S. senator" gender (female) & $\begin{array}{l}(.068) \\
-.096 *\end{array}$ & & \\
\hline $\begin{array}{l}\text { Female member of Congress** } \\
\text { gender (female) }\end{array}$ & $\begin{array}{c}(.048) \\
-.089 \\
(.080)\end{array}$ & & \\
\hline \multicolumn{4}{|l|}{ Substantive representation } \\
\hline Party congruence governor & $\begin{array}{l}.011 \\
(.030)\end{array}$ & $\begin{array}{l}.007 \\
(.047)\end{array}$ & $\begin{array}{l}.021 \\
(.047)\end{array}$ \\
\hline Party congruence senator & $\begin{array}{l}.031 \\
(.032)\end{array}$ & $\begin{array}{l}.028 \\
(.051)\end{array}$ & $\begin{array}{l}.033 \\
(.052)\end{array}$ \\
\hline Party congruence House & -.007 & .028 & -.043 \\
\hline $\begin{array}{l}\text { Proportion of party congruence } \\
\text { in state legislature }\end{array}$ & $\begin{array}{c}-.001 \\
-.001)\end{array}$ & $\begin{array}{l}-.001 \\
-.001)\end{array}$ & $\begin{array}{l}-.000 \\
-.001)\end{array}$ \\
\hline Gender (female) & $\begin{array}{l}.001 \\
.005 \\
(.056)\end{array}$ & & \\
\hline \multicolumn{2}{|l|}{ Strength of party identification } & .064 & .085 \\
\hline State political culture & $\begin{array}{l}.0110 \\
-.010\end{array}$ & -.006 & $-.015 \#$ \\
\hline Voter & $.120^{* * * \ldots * n}$ & 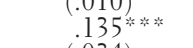 & $.100 * * ;$ \\
\hline Church attendance & $\begin{array}{l}(.026) \\
.012\end{array}$ & $\begin{array}{l}(.034) \\
.015\end{array}$ & $\begin{array}{l}(.034) \\
.009\end{array}$ \\
\hline \multirow{2}{*}{\multicolumn{4}{|c|}{ Internal efficacy }} \\
\hline & & & \\
\hline \multicolumn{4}{|c|}{$(.077)$} \\
\hline \multicolumn{4}{|l|}{ Income } \\
\hline \multicolumn{4}{|r|}{$-.019 * * *$} \\
\hline \multicolumn{4}{|l|}{ Age-squared } \\
\hline \multicolumn{4}{|l|}{ Homemaker } \\
\hline \multicolumn{4}{|l|}{ Race (black) } \\
\hline \multirow{2}{*}{\multicolumn{4}{|c|}{ Cut 1}} \\
\hline & & & \\
\hline \multicolumn{4}{|l|}{ Cut 2} \\
\hline \multicolumn{4}{|r|}{$(.162)$} \\
\hline \multicolumn{4}{|r|}{$2.299 * * * *$} \\
\hline Wald chi ${ }^{2}$ & 26157.90 (113) & $4422.59^{(.157)}$ & $1441.80^{(.156)}$ \\
\hline & & 4,776 & 4,020 \\
\hline
\end{tabular}

Note: Standard errors are in parentheses, ${ }^{\mathrm{p}} \mathrm{p}<.10,{ }^{*} \mathrm{p}<.05,{ }^{* * *} \mathrm{p}<.01$, ${ }^{* * *} \mathrm{p}<.001$, two-tailed test 
increase females' confidence in government relative to men. ${ }^{20}$ Examining the model separately for female and male respondents confirms what we see in the interactive model. In the female model, the proportion of women in state legislatures is positive, indicating that greater levels of female representation increase female citizens' feelings about government responsiveness. This is not the case in the male model, which shows no effect of collective female descriptive representation in the statehouse on external efficacy. Given that this is our most robust measure of collective descriptive representation, we view these results as supportive of our hypothesis.

There is little evidence to support the idea that dyadic descriptive, dyadic substantive, or collective substantive representation influences levels of external efficacy. The dyadic descriptive representation variables are largely insignificant across models, except for the presence of a female senator for women in the interaction model, which is negative. At the least, these data show no support for the notion that dyadic descriptive representation enhances external efficacy.

Meanwhile, as expected, there are a number of positive and significant controls, including internal efficacy, education, voting, income, and strength of party identification. The relationship between age and external efficacy is curvilinear.

To compare the effects of collective descriptive representation on male and female citizens, we graphed the expected probabilities for both genders' external efficacy at the minimum and maximum values of collective descriptive representation. For the percentage of women in the state legislature, this is $4 \%$ and $40 \%$, respectively; and for female governor, this is 0 and 1 , respectively. All other independent variables were held at their mean or mode in the case of electoral dummies. ${ }^{21}$ Figure 1 shows the results, and as expected, the effect is much stronger for females. Males are somewhat more likely to have low external efficacy ( 1 or 2 ) when collective female state descriptive representation is low, compared to when it is high, females much more so. For example, the probability that a female has an external efficacy score at the lowest level (1) is 19\% when collective descriptive representation is lowest, but only $10 \%$ when collective descriptive representation is highest. Similarly, when collective descriptive representation is increased to its maximum, the probability that a female has an external efficacy score of 2 drops from $42 \%$ to $36 \%$.

20. This is true in a reduced model that contains the demographic and main theoretical variables.

21. We used the software program Clarify for this task (Tomz, Wittenberg, and King 2000). 


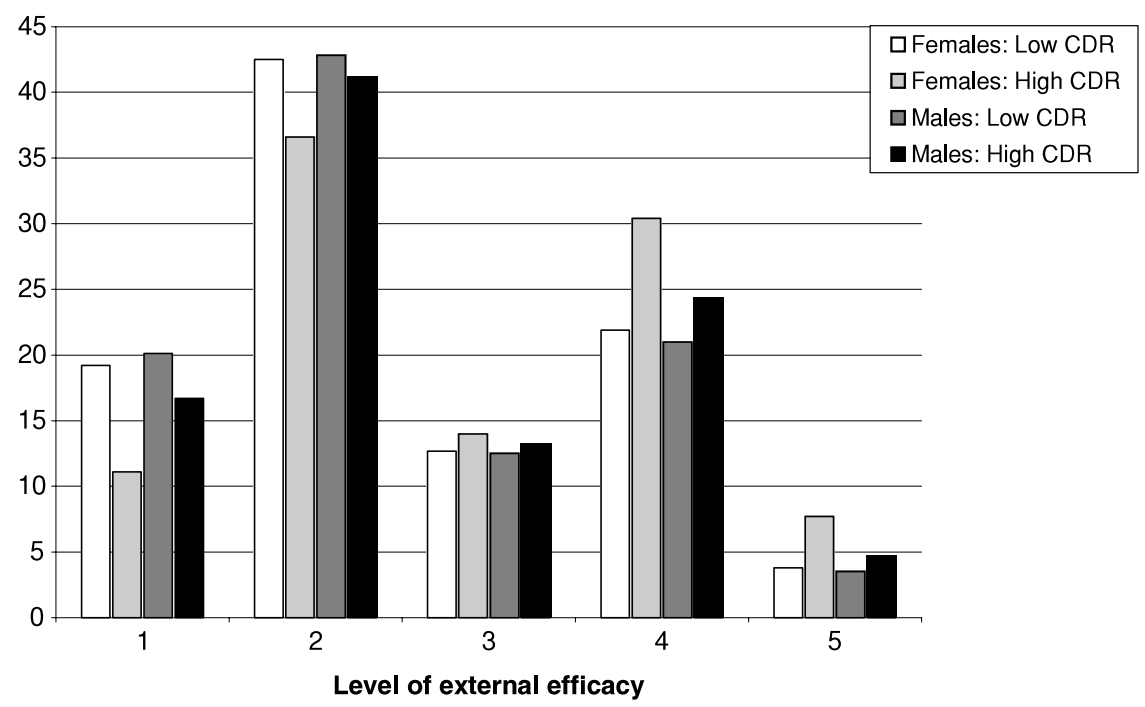

Figure 1. Expected probabilities for women and men at minimum and maximum levels of collective descriptive representation (state legislature and female governor).

Altogether, changing collective descriptive representation moves about $15 \%$ of females out of the lowest levels of external efficacy. For men, the same change moves about $7 \%$ of them out of the lowest levels of external efficacy.

Similarly, when the proportion of women in the state legislature is high, citizens are more likely to have midlevel or higher scores, especially among females. When collective descriptive representation moves from its lowest to its highest values, the expected probability that a female has an external efficacy score of 4 moves from $22 \%$ to $31 \%$. The probability that a female has an external efficacy score of 5 , the highest possible value, doubles from $4 \%$ to $8 \%$. Altogether, $14 \%$ of females move to high levels of external efficacy by increasing collective descriptive representation. The corresponding value for males is $6 \%$.

Using the same technique and examining the impact of the proportion of women in state legislatures by itself while holding female governor at its mean, we can see in Figure 2 that this variable impacts female citizens but not male citizens. A total of $10 \%$ of females move out of the lowest levels of external efficacy ( 1 or 2 ) by increasing the percentage of women in the state legislature from $4 \%$ to $40 \%$. Most of these females, 


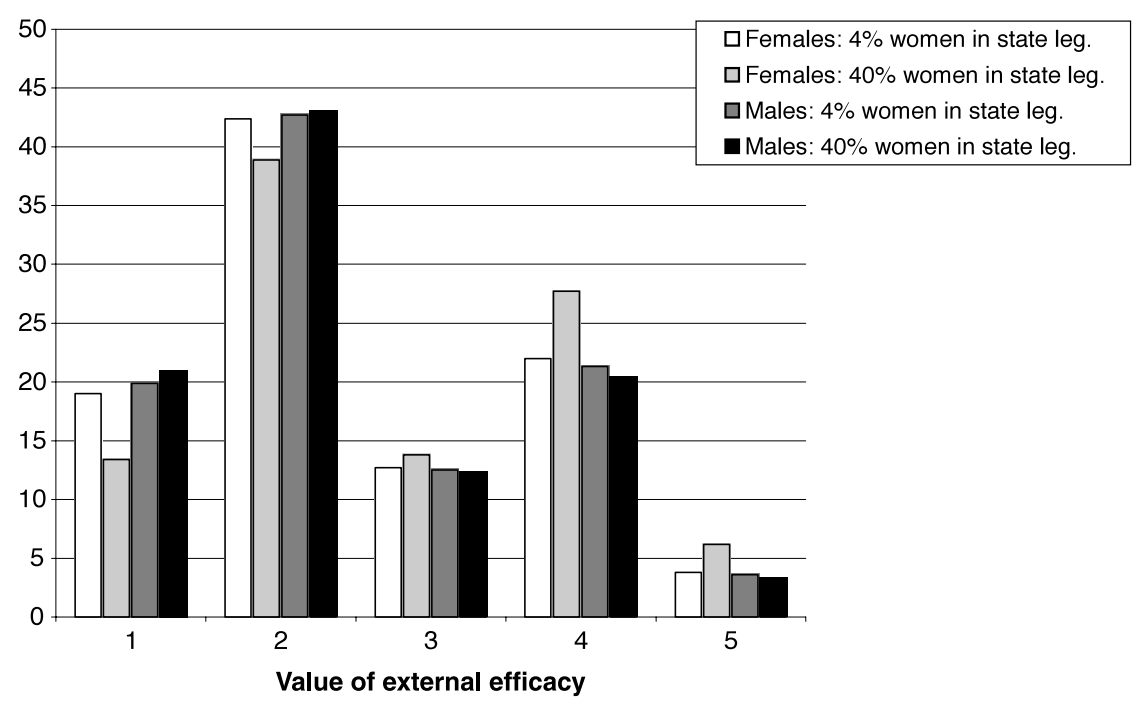

Figure 2. Expected probabilities for women and men at low and high levels of women in the state legislature.

9\%, move into the highest levels of external efficacy (4 or 5). Among men, the proportion of women in the state legislature has no impact on external efficacy.

Finally, we examined the impact of woman governor while holding the proportion of women in state legislatures at its mean. Figure 3 indicates extremely similar trends between males and females. By having a woman governor, about 5\% of both men and women move out of the lowest levels of external efficacy ( 1 or 2 ) and into the highest levels of external efficacy.

\section{CONCLUSION}

The results show that collective female representation influences external efficacy in a positive way. When greater proportions of female state legislators are present, the likelihood that women feel better about government, and hence the democratic society in which they live, improves. Moreover, when we look at the female model, we find even stronger support for our theoretical framework. Thus, this analysis provides support for the theoretical argument that collective descriptive rep- 


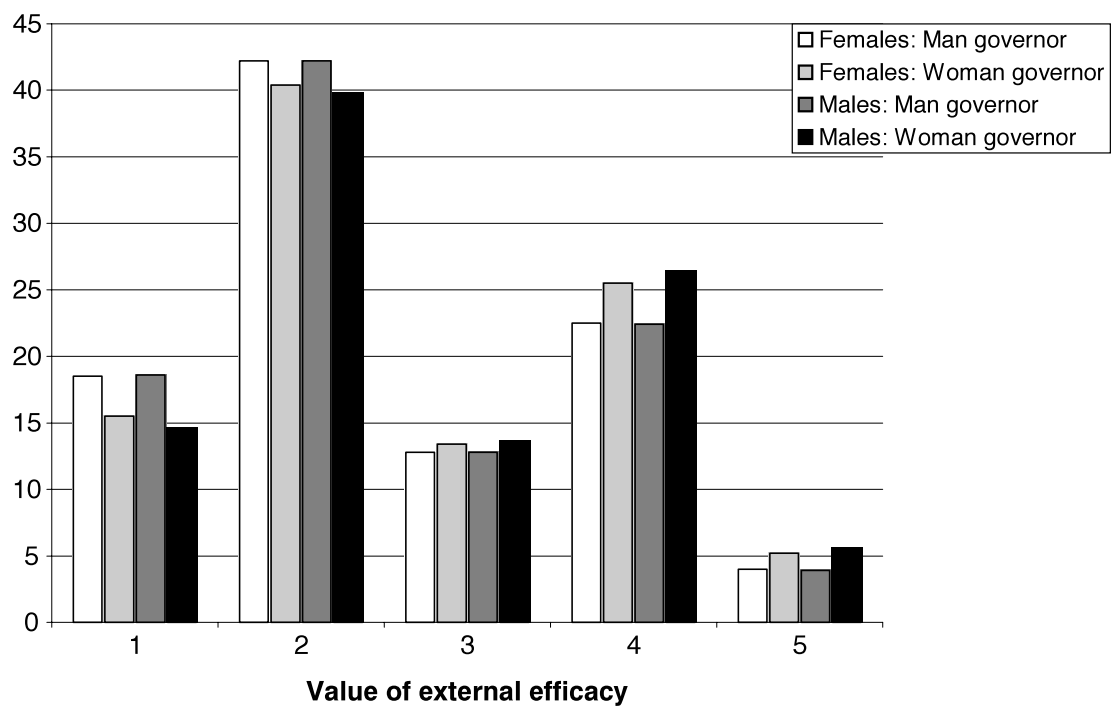

FigurE 3. Expected probabilities for women and men with male and female governors.

resentation enhances government legitimacy. We, however, discover no support for the notion that dyadic representation matters, a finding that is increasingly supported in other research as well. Representation, therefore, needs to be considered in its broader form of collective representation, rather than the more narrow dyadic representation.

We find an intriguing result that men are influenced by the presence of a woman governor, and the weight of the evidence suggests that women citizens are as well. Future research will have to examine whether this is an artifact or a real effect. If it is a real effect, one possible theoretical reason is that visible executive women bring a different set of characteristics to the office, which enhances representation for all and, hence, improves all citizens' feelings of government responsiveness.

An alternative interpretation of these results is that the causal direction is reversed, suggesting that a greater level of female external efficacy produces larger proportions of female legislators. This explanation, however, is neither theoretically nor empirically convincing. Theoretically, it is unlikely that modest gains in the external efficacy of citizens would increase the odds of women in the eligible pool of candidates to run for office. The potential legislator pool typically includes those who have greater levels of education and come from middle- or upper-class back- 
grounds and therefore come from a different "social and political strata than does their public" (Darcy, Welch, and Clark 1994, 107). Moreover, Richard Fox and Lawless $(2004,272)$ find that the attitude "qualification" is one of two important factors inducing women to run for political office, signifying that it is personal attitudes, rather than mass attitudes, that contribute to a potential female candidate's decision to run for office. ${ }^{22}$ Finally, to our knowledge, no known theoretical framework predicts that greater levels of external efficacy at the mass level enhance candidate recruitment, which would in turn increase the collective descriptive representation of the legislative body. Thus, it is our contention that this alternative is unlikely.

Instead, these results suggest an important role for collective descriptive representation in shaping attitudes and behaviors in a democratic society. Because those who believe government is more responsive are also more politically active in a number of areas of political life, greater female representation may indirectly impact the political engagement of women citizens. This hypothesis is consistent with increasing evidence suggesting that descriptive representation more generally has other positive benefits on political engagement (see Atkeson 2003; Burns, Schlozman, and Verba 2001). Because external efficacy measures a primary democratic expectation, government responsiveness, it is a particularly appropriate attitude for examining the role of collective descriptive representation, which remains an understudied concept. Finally, this research may have implications for other descriptively underrepresented groups, including blacks, Latinos, and Asian Americans. Additional research may find that increases in collective minority descriptive representation may play an important role in forming attitudes for these groups as well. Indeed, a study by Gordon and Segura (2002) suggests a role for collective Latino representation in feelings about the job performance of the California state legislature, and consistent with this study, they find no effect of dyadic Latino representation on political efficacy.

In general, this finding sheds new empirical light on the value of collective descriptive representation. While in the past, descriptive representation has been largely dismissed because it is not necessary for substantive representation (Pitkin 1967), this research suggests an alternative and important role for collective descriptive representation. Specifically, this research shows that recent theories that argue that descriptive

22. The other factor Fox and Lawless (2004) consider is being encouraged to run for office. 
representation enhances government legitimacy may be right. We find that the greater presence of one underrepresented group in the elected halls of government enhances feelings of government responsiveness among these citizens. In this way, collective descriptive representation may ultimately help to create both a stronger and healthier democratic system.

\section{REFERENCES}

Abramson, Paul R. 1983. Political Attitudes in America. San Francisco: Freeman.

Abramson, Paul R., and John H. Aldrich. 1982. "The Decline of Electoral Participation in America.” American Political Science Review 76 (3): 502-21.

Alvarez, Michael R., and Edward J. McCaffery. 2000. "Gender and Tax." In Gender and American Politics: Women, Men and the Political Process, ed. Sue Tolleson-Rinehart and Jyl J. Josephson. Armonk, NY: Sharpe, 91-113.

Atkeson, Lonna Rae. 2003. "Not All Cues Are Created Equal: The Conditional Impact of Female Candidates on Political Engagement." Journal of Politics 65 (4): 1040-61.

Balch, George I. 1974. "Multiple Indicators in Survey Research: The Concept 'Sense of Political Efficacy.'" Political Methodology 1 (1): 1-43.

Barrett, Edith. 1995. "The Policy Priorities of African-American Women in State Legislatures." Legislative Studies Quarterly 20 (2): 223-47.

Berkman, Michael B. and Robert E. O'Connor. 1993. "Do Women Legislators Matter? Female Legislators and State Abortion Policy." American Politics Quarterly 21 (1): $102-24$.

Bratton, Kathleen A., and Kerry L. Haynie. 1999. "Agenda Setting and Legislative Success in State Legislatures: The Effects of Gender and Race." Journal of Politics 61 (3): $658-79$.

Burns, Nancy, Kay Lehman Schlozman, and Sidney Verba. 2001. The Private Roots of Public Action: Gender, Equality and Political Participation. Cambridge, MA: Harvard University Press.

Burrell, Barbara. 1997. "The Political Leadership of Women and Public Policymaking." Policy Studies Journal 25 (4): 565-68.

Campbell, Angus, Philip E. Converse, Warren E. Miller, and Donald E. Stokes. 1960. The American Voter. New York: Wiley.

Carey, John M., Richard G. Niemi, and Lynda W. Powell. 1998. "Are Women State Legislators Different?” In Women and Elective Office: Past, Present and Future, ed. Sue Thomas and Clyde Wilcox. New York: Oxford University Press, 87-102.

Carroll, Susan J. 1984. "Feminist Scholarship on Political Leadership." In Leadership: Multidisciplinary Perspectives, ed. Barbara Kellerman. Englewood Cliffs, NJ: Prentice-Hall, 139-56.

Citrin, J., and D. P. Green. 1986. "Presidential Leadership and the Resurgence of Trust in Government." British Journal of Political Science 16 (4): 431-53.

Claibourn, Michele, and Virginia Sapiro. 2001. "Gender Differences in Citizen-Level Democratic Citizenship: Evidence from the Comparative Study of Electoral Systems." Paper presented at the Midwest Political Science Association Convention, Chicago.

Clarke, Harold D., and A. C. Acock. 1989. "National Elections and Political Attitudes: The Case of Political Efficacy." British Journal of Political Science 19 (4): 551-62. 
Converse, Philip E. 1972. "Change in the American Electorate." In The Human Meaning of Social Change, ed. Angus Campbell and Philip E. Converse. New York: Sage, 263-337.

Craig, Steven C., Richard G. Niemi, G. E. Silver. 1990. "Political Efficacy and Trust: A report on the NES Pilot Study Items." Political Behavior 12 (3): 289-314.

Crowley, Jocelyn Elise. 2004. "When Tokens Matter." Legislative Studies Quarterly 29 (1): 109-36.

Darcy, R., Susan Welch, and Janet Clark. 1994. Women, Elections, and Representation. Lincoln: University of Nebraska Press.

Day, Christine L. 1994. "State Legislative Voting Patterns on Abortion Restrictions in Louisiana. Women and Politics 14 (1): 45-63.

Delli Carpini, Michael, and Scott Keeter. 1996. What Americans Know About Politics and Why it Matters. New Haven: Yale University Press.

Diamond, Irene. 1977. Sex Roles in the State House. New Haven: Yale University Press.

Dodson, Debra L., and Susan J. Carroll. 1991. Reshaping the Agenda: Women in State Legislatures. New Brunswick, NJ: Center for American Women and Politics.

Dovi, Suzanne. 2002. "Preferable Descriptive Representatives: Will Just Any Woman, Black or Latino Do?" American Political Science Review 96 (4): 729-43.

Elazar, Danile J. 1984. American Federalism: A View from the States. 3d ed. New York: Harper \& Row.

Erber, R. and Rick R. Lau. 1990. "Political Cynicism Revisited: An Information Processing Reconciliation of Policy-Based and Incumbency-Based Interpretations of Changes in Trust in Government." American Journal of Political Science 34 (1): 236-53.

Finkel, Steven E. 1985. "Reciprocal Effects of Participation and Political Efficacy: A Panel Analysis." American Journal of Political Science 29 (4): 891-913.

Finkel, Steven E. 1987. "The Effects of Participation of Political Efficacy and Political Support: Evidence from a West German Panel." Journal of Politics 49 (2): 441-64.

Fox, Richard L., and Jennifer L. Lawless. 2004. "Entering the Arena? Gender and the Decision to Run for Office." American Journal of Political Science 48 (2): 264-80.

Ginsberg, Benjamin. 1982. The Consequences of Consent: Elections, Citizen Control and Popular Acquiescence. Reading, MA: Addison-Wesley.

Ginsberg, Benjamin, and R. Weissberg. 1978. "Elections and the Mobilization of Popular Support." American Journal of Political Science 22 (1): 31-55.

Gordon, Stacy Burnett, and Gary M. Segura. 2002. "Looking Good . . . Feeling Good! Assessing Whether Dyadic and Collective Descriptive Representation Shape Latino Attitudes Towards Government." Paper presented at the Annual Meeting of the American Political Science Association, Boston, August 28-September 1.

Hansen, Susan B. 1997. "Talking about Politics: Gender and Contextual Effects on Political Proselytizing." Journal of Politics 59 (1): 73-103.

Hayes, Bernadette C., and Clive S. Bean. 1993. "Political Efficacy: A Comparative Study of the United States, West Germany, Great Britain and Australia." European Journal of Political Research 23 (2): 261-80.

Hero, Rodney E., and Caroline J. Tolbert. 1995. "Latinos and Substantive Representation in the US House of Representatives: Direct, Indirect or Nonexistent." American Journal of Political Science 39 (3): 640-52.

Hill, David B. 1981. "Political Culture and Female Political Representation." Journal of Politics 43 (1): 159-68.

Hinckley, Barbara, Richard Hofstetter, and John Kessel. 1974. "Information and the Vote: A Comparative Election Study." American Politics Quarterly 2 (1): 131-58. 
Hougland, James G., Jr., and James A. Christenson. 1983. "Religion and Politics: The Relationship of Religious Participation to Political Efficacy and Involvement." Sociology and Social Research 67 (4): 406-20.

Huddy, Leonie, and Nayda Terkildsen. 1993. "The Consequences of Gender Stereotypes for Women Candidates at Different Levels and Types of Office." Political Research Quarterly 46 (3): 503-25.

Keiser, Lael R., Vicky M. Wilkins, Kenneth J. Meier, and Catherine A. Holland. 2002. "Lipstick and Logarithms: Gender, Institutional Context and Representative Bureaucracy." American Political Science Review 96 (3): 553-64.

Koch, Jeffrey, 1997. "Women's Engagement in Politics in the Year of the Woman." American Politics Quarterly 25 (1): 118-33.

Lawless, Jennifer L. 2004. "Politics of Presence? Congresswomen and Symbolic Representation." Political Research Quarterly 57 (1): 81-99.

Leader, Shelah Gilber. 1977. "The Policy Impact of Elected Women Officials." In The Impact of the Electoral Process, ed. Louis Maisel and Joseph Cooper. Beverly Hills, CA: Sage, 265-84.

Leeper, Mark S. 1991. “The Impact of Prejudice on Female Candidates: An Experimental Look at Voter Inference." American Politics Quarterly 19 (2): 248-61.

Mandel, Ruth B., and Debra L. Dodson. 1992. "Do Women Officeholders Make a Difference?” In The American Woman, 1992-95, ed. Sara E. Rix. New York: Norton, $149-77$.

Mansbridge, Jane. 1999. "Should Blacks Represent Blacks and Women Represent Women? A Contingent 'Yes.'” Journal of Politics 61 (3): 628-57.

Morrell, Michael E. 2003. "Survey and Experimental Evidence or a Reliable and Valid Measure of Internal Political Efficacy." Public Opinion Quarterly 67 (4): 589-602.

Mueller, Carol M. 1986. "Nurturance and Mastery: Competing Qualifications for Women's Access to High Public Office?” In Women and Politics: Activism, Attitudes and Office-Holding. Research in Politics and Society, Vol. 2, ed. Gwen Moore and Glenna Spitze. Greenwich, CT: JAI Press, 211-32.

Murphy, Patricia. 1997. Domestic Violence Legislation and the Police: The Role of SocioEconomic Indicators, Political Factors and Women's Political Activism on State Policy Adoption." Women and Politics 18 (2): 27-50.

Nechemias, Carol. 1985. "Geographic Mobility and Women's Access to State Legislatures." Western Political Quarterly 38 (1): 119-31.

Nechemias, Carol. 1987. "Changes in the Election of Women to US State Legislative Seats." Legislative Studies Quarterly 12 (1): 125-42.

Norrander, Barbara, and Clyde Wilcox. 1998. "The Geography of Gender Power: Women in State Legislatures." In Women in Elective Office: Past, Present and Future, ed. Sue Thomas and Clyde Wilcox. New York: Oxford University Press, 103-17.

Pantoja, Adrian D., and Gary M. Segura. 2002. "Does Ethnicity Matter? Descriptive Representation in the Statehouse and Political Alienation Among Latinos." Presented at the Annual Meeting of the Midwest Political Science association, Chicago, April 25-27.

Phillips, Anne. 1998. "Democracy and Representation: Or, Why Should It Matter Who Our Representatives Are?" In Feminism and Politics, collection of readings with introduction, Oxford: Oxford University, 224-40.

Pitkin, Hanna. 1967. The Concept of Representation. Berkeley: University of California Press.

Pollock, Philip H., III. 1983. “The Participatory Consequences of Internal and External Political Efficacy: A Research Note.” Western Political Quarterly 36 (3): 400-409. 
Reingold, Beth. 2000. Representing Women: Sex, Gender and Legislative Behavior in Arizona and California. Chapel Hill: University of North Caroline Press.

Rosenstone, Steven J., and John Mark Hansen. 1993. Mobilization, Participation, and Democracy in America. New York: MacMillan.

Rosenthal, Cindy Simon. 1998. When Women Lead: Integrative Leadership in State Legislatures. Oxford: Oxford University Press.

Rosenwasser, Shirley M., and Jana Seale. 1988. "Attitudes Toward a Hypothetical Male or Female Candidate-A Research Note.” Political Psychology 9 (4): 591-98.

Saint-Germain, Michelle A. 1989. "Does Their Difference Make a Difference? The Impact of Women on Public Policy in the Arizona Legislature.” Social Science Quarterly 70 (4): 956-68.

Saltzstein, Grace H. 1979. "Black Mayors and Police Policies." Journal of Politics 51 (3): 525-44.

Sapiro, Virginia. 1981. "When Are Interests Interesting?" American Political Science Review 75 (3): 701-21.

Sapiro, Virginia. 1981/82. "If US Senator Baker Were a Woman: An Experimental Study of Candidate Images." Political Psychology 2 (1): 61-83.

Sapiro, Virginia. 1983. The Political Integration of Women: Roles, Socialization and Politics. Urbana: University of Illinois Press.

Sapiro, Virginia, and Pamela Johnston Conover. 1997. “The Variable Gender Basis of Electoral Politics: Gender and Context in the 1992 US Election. British Journal of Political Science 27 (4): 497-523.

Schwindt-Bayer, Leslie A., and William Mishler. 2005. "The Nexus of Representation: An Integrated Model of Women's Representation." Journal of Politics 67 (2): 407-28.

Shapiro, Robert Y., and Harpreet Mahajan. 1986. "Gender Differences in Policy Preferences: A Summary of Trends from the 1960s to the 1980s." Public Opinion Quarterly 50 (1): 42-61.

Sharkansky, Ira. 1969. “The Utility of Elazar’s Political Culture.” Polity 2 (1): 66-83.

Shingles, Richard D. 1981. "Black Consciousness and Political Participation: The Missing Link.” American Political Science Review 75 (1): 76-91.

Soss, Joe. 1999. "Lessons of Welfare: Policy Design, Political Learning and Political Action." American Political Science Review 93 (2): 363-78.

Squire, Peverill, and Christina Fastnow. 1994. "Comparing Gubernatorial and Senatorial Elections." Political Research Quarterly 47 (3): 705-20.

Stenner-Day, Karen, and Mark Fischle. 1992. "The Effects of Political Participation of Political Efficacy: A Simultaneous Equations Model." Australian Journal on Political Science 27 (2): 282-305.

Stewart, Marianne C., Allan Kornberg, Harold D. Clarke, and Alan Acock. 1992. "Arenas and Attitudes: A Note on Political Efficacy in a Federal System." Journal of Politics 54 (1): 179-96.

Tate, Katherine. 2001. “The Political Representation of Blacks in Congress: Does Race Matter?” Legislative Studies Quarterly 26 (4): 623-38.

Tate, Katherine. 2003. Black Faces in the Mirror: African Americans and Their Representatives in the U.S. Congress. Princeton: Princeton University Press.

Thomas, Sue. 1991. “The Impact of Women on State Legislative Policies." Journal of Politics 53 (4): 958-76.

Thomas, Sue. 1994. How Women Legislate. New York: Oxford University Press.

Thomas, Sue, and Susan Welch. 1991. "The Impact of Gender on Activities and Priorities of State Legislators." Western Political Quarterly 44 (2): 445-56.

Thompson, Frank J. 1976. "Minority Groups in Public Bureaucracies: Are Passive and Active Representation Linked?” Administration and Society 8 (August): 201-26. 
Tidmarch, Charles M., Lisa J. Hyman, and Jill E. Sorkin. 1984. "Press Issue Agendas in the 1982 Congressional and Gubernatorial Election Campaigns." Journal of Politics 46 (4): 1226-42.

Tolbert, Caroline, and Trudy A. Steuernagel. 2001. "Women Lawmakers, State Mandates and Women's Health." Women and Politics 22 (2): 1-39.

Tomz, Michael, Jason Wittenberg, and Gary King. 2000. “CLARIFY: Software for Interpreting and Presenting Statistical Results." Version 1.2.2. March 3. Cambridge, MA: Harvard University. http://gking.harvard.edu (July 15, 2006).

Verba, Sidney, Nancy Burns, and Kay Lehman Schlozman. 1997. "Knowing and Caring about Politics: Gender and Political Engagement." Journal of Politics 59 (4): 1051-72.

Weissberg, Robert. 1978. "Collective vs. Dyadic Representation in Congress." American Political Science Review 72 (2): 535-47.

Weldon, S. Laurel. 2002. "Beyond Bodies: Institutional Sources of Representation for Women in Democratic Policymaking." Journal of Politics 64 (4): 1153-74.

Whicker, Marcia Lynn, and Malcolm Jewell. 1998. "The Feminization of Leadership in State Legislatures." In Women in Elective Office: Past, Present and Future, ed. Sue Thomas and Clyde Wilcox. New York: Oxford University Press, 163-74. 